\title{
An Investigation of the Job Performance of Administrative Staff in Government Hospitals, Malaysia
}

\author{
Suguna Sinniah ${ }^{1}$, Ramesh Kumar Moona Haji Mohamed ${ }^{2}$, Vimala Kadiresan ${ }^{1}$, Prem Kumar Nadarajan², Adam \\ Arif Lee Aik Keang ${ }^{2}$, Azeyan Awee ${ }^{2} \&$ Che Siti Lazrina Md Lazim² \\ ${ }^{1}$ Faculty of Business, Accountancy and Management, SEGi University, Kota Damansara, Selangor, Malaysia \\ ${ }^{2}$ Faculty of Business and Finance (FBF), Universiti Tunku Abdul Rahman, Kampar, Perak, Malaysia \\ Correspondence: Suguna Sinniah, Faculty of Business, Accountancy and Management, SEGi University, Kota \\ Damansara, Malaysia. E-mail: suguna@segi.edu.my
}

Received: June 15, 2018

doi:10.5539/ijbm.v13n10p38
Accepted: August 10, 2018 Online Published: September 6, 2018

URL: https://doi.org/10.5539/ijbm.v13n10p38

\begin{abstract}
Stress can cause a negative effect on the psychological condition and affect the overall job performance of an employee. The aim of this study is to examine the relationship between job stress and job performance among administrative staff in Selangor (state of Malaysia) Hospitals. Probability sampling techniques were used as the name of the respondents and a simple random sampling was used to conduct this study. List of Government Hospitals has been obtained from the official website and the directory of Ministry of Health Malaysia. The results show that all the variables such as work stress, workload, work-life conflict time pressure, and social pressure significantly influence the job performance of Hospital administrative staffs. The research results help to improve employee performance by understanding the behavior and attitudes of hospital staff against work stress. The implication of the study has been explaining in detail with limitation and future research study for his current research.
\end{abstract}

Keywords: psychological, performance, administrative, government, ministry of health

\section{Introduction}

In recent years, all employees and employers are exposed to the stressful work-life environment. There were exposed more intensively than others. The previous researchers use the term of stress as a feeling of fatigue, distress, and inability to cope meanwhile (Arshadi \& Damiri, 2013) had defined stress as a person's response to the attributes of work environment which seems to be emotionally and physically threatening. At the same time (Yozgat, Yurtkoru, \& Bilginoglu, 2013) says that whenever there is an increase in job demand and employee ability, job stress also increase. Work pressure is defined as a physical and mental change either positively or negatively impact the performance of an organization. Not all the job scope encounter the same level of stress and it's depending on the disruption on the work environment. As said by (Hsieh, Huang, \& Su, 2004) some employees wouldn't adopt the given work environment meanwhile (Ismail \& Tan, 2011) argued in their research that the employees are facing high work pressure due to not matching technical ability with their interpersonal ability. At the same time (Arandelovic \& Ilic, 2006) says that work stress also leads to high job demands and weak in controlling the situation. Work stress and job performance has a significant relationship, including climate organization, staff development, working environment and adaptations, mental, behavioral responses and physical (Hsieh et al., 2004). Past researchers results shows that job performance positively impacted by leaders emotion's, inbound and outbound open innovation, self-estrangement, organization culture of both foreign and Malaysian perspective (Choudhary, Naqshbandi, Philip, \& Kumar, 2017; Naqshbandi, Garib Singh, \& Ma, 2016; Golden \& Veiga, 2016; Naqshbandi, Kaur, Sehgal, \& Subramaniam, 2015; Golden \& Gajendran, 2018) Employee work stress can affect overall performance. Ismail \& Tan (2011), found that the main reason for the dissatisfaction with work and poor performance arise from stress. S.Suguna (2017) says in her research that human resources practices play an important role in enhancing overall job performance in the service industry.

Malaysia has been reported on a shortage of 9000 medical officers and experts as well as total $40 \%$ vacancies in clinics, private and government healthcare providers. Many efforts have been taken to attract the working abroad Malaysian doctors to return and serve the country, so far only some have returned. As a result, the current Malaysia located doctor who is appearing at public hospitals forced to work long hours, which lead to high level 
of stress. At the same time, the administrators work under pressure by undertaking the unfinished task by doctors and high paperwork.

Many studies have looked at the effects of high-stress level. Researchers have studied stress level in various industries in Malaysia. However, there has not been a lot of attention given to the relationship between factors of stress towards job performance specifically among government health care providers. This research is aim to investigate on how factors of stress impact job performance among government hospitals in one of the states in Malaysia. Variables such as work stress, workload, time pressure, work-life conflict and social pressure influence will be evaluated in this study. This research is important for all the hospital workers includes managers and staff. Hospital managers should introduce training such as time management and on how to handle stress administrative staff. It will be the best solutions to improve their attitude to deal with the high pressures of work and to understand the clear objective of the management.

Finally, the quality of the administrative staff also will be enhanced lead to a better credibility for their organization. It will also upgrade the Hospital's reputation indirectly build a trust towards the service provided.

\section{Research Objectives}

1. To investigate the relationship between work stress and job performance among the administrative staff of Hospitals.

2. To investigate the relationship between workload and job performance among the administrative staff of Hospitals.

3. To investigate the relationship between time pressure and job performance among the administrative staff of Hospitals.

4. To investigate the relationship between work-life conflict and job performance among the administrative staff of Hospitals.

5. To investigate the relationship between the pressure of social influence and job performance among the administrative staff of Hospitals.

\section{Literature review}

\subsection{The Work Stress and Job Performance}

Job stress is being a common problem in the current era and it's being an epidemic in the working environment. Work stress is stress sources and task-related sources of job stress (Vandenberghe, Panaccio, Bentein, Mignonac, \& Roussel, 2011). Job stress is the psychophysiological arousal resulting from workplace demands. Optimally, it results in enhanced job performance. When mismanaged, job stress leads to job strain, which includes psychological, medical, and behavioral costs (Pasha, Poister, Wright, \& Thomas, 2017). (Yozgat, Yurtkoru, \& Bilginoğlu, 2013) says that lower level managers experience more stress compare to high-level managers. In past researches, work stress being appraised consistently by role ambiguity, role conflict and role overload which being three critical sources of work stress (Wallace, Edwards, Arnold, Frazier, \& Finch, 2009). (Vickie A. Lambert DNSc, FAAN Clinton E. Lambert Ph.D., 2001) stated that response on the work stress varies by individuals. This differences can cause by their personal features, work itself or the circumstances related to the firm. Meanwhile (Mulki, Jaramillo, Goad, \& Pesquera, 2015) mentioned in their research that emotions are conducive to reduce stress and less stress eventually leads to higher performance by the employees. As such the below hypothesis was developed:

H1: Work stress has a negative relationship with job performance.

\subsection{Workload and Job Performance}

Work overload occurs when the demand exceeds capabilities or when too much expected within a short time frame.

(De Cremer, Van Dick, \& Murnighan, 2011). Many studies associated with workload towards job performance found both positive and negative effects of stress been detected with the mixed results (Bruggen, 2015). (López \& Peters, 2012) stated that pressure-related workload will affect the quality of an employee. Oron-Gilad, Szalma, Stafford, \& Hancock (2008) study found that when workload increases the job performance of an employee decrease. Meanwhile (Bruggen, 2015) mentioned that employee performance is affected by the different level of workload and it is important to assess the effect to improve their capacity decision in an organization. Moderate level of the workload will always improve performance because employees perform their tasks effectively. Low level of stress may lead to too low effective performance. The different result shown in various studies hence 
workload is been chosen for this research to identify the impact towards Hospital Staff. Hence the following hypothesis was formulated:

$\mathrm{H} 2$ : Workload has a negative relationship with job performance

\subsection{Time Pressure with Job Performance}

Kelley et al. (2005) study on 374 workers in the public accounting firm in the nation found that pressure or a work deadline will affect employee behavior, such as effectiveness, efficiency and a reduction in the quality and action. Significant results showed from paired comparison t-test among workers detected on time and budget pressure measurement deadlines at the time of audit effectiveness and efficiency. However, employees feel more time budget pressure has to do with the quality of audits compared with the pressure of time deadlines. Gomaa (2005) assessed that the workers who make decisions about time more associated with time pressure. Apart from the pressure of time, the study also tested with other variables, where the complexity of the task and the risk of legal action. 235 workers from two "big-four" public accounting firm in the United States participated in this study. ANOVA analysis results show that there is a positive relationship between the pressure and dependence on aid workers decision. As such the following hypothesis was formulated:

H3: Time pressure has a negative relationship with job performance.

\subsection{Work-Life Conflict with Job Performance}

Work life conflict is a form of inter-role conflict where the role pressures from work mutually incompatible with family domains in some aspects. According to (Tabassum, Rahman, \& Jahan, 2011) examine the family-work conflict are spouse and family support. While Young, Wallace, \& Polachek (2015) used social support which is measured by four variables: co-workers support, organizational support, spouse (emotional) support and spouse (career) support. In terms of the impacts that can be caused by the conflict, according to Cornwall \& Rivas (2015), the conflict is able to give positive and negative effects. It is similar to Usman's views (2013), conflict can have a positive impact and can also be a negative impact on the individual's life. Employee performance drop when they work more hours which lead to less quality time with family (Khan, Khan, Khan, and Shakeel 2011; Daugherty, Dickins, and Higgs, 2009). (Gilboa, Shirom, Fried, \& Cooper, 2008) stated that poor decision between work-life conflict and performance reflects the lack of legitimacy in their review of the work environment for work-life conflict that can affect job performance. Quality of life or issues of work-life conflict can have negative effects on the quality of employees as it may require relocation and additional training to understand the operation of new clients. As a result, the following hypothesis was developed:

H4: Work life conflict has a negative relationship with job performance.

\subsection{Influence of Social Stress with Job Performance}

God and DeZoort (2001) examine whether the pressure of social influence in terms of adherence and compliance stress can affect workers decision to approve the financial statements disclosures of material. Meanwhile, Chong and inclusion (2010) found stress obedience affects the project manager assessment results with 122 management accounting courses students in Australia. The study of Independent sample t-tests was performed and the resulted that managers are prone to stress obedience more likely to fail to proceed with the project. Clayton, Staden, and Lynch (2010) investigated whether the social influence of pressure is not appropriate in terms of ethical thinking and consideration of obedience and compliance pressures influence people. As such the following hypothesis was developed:

H5: Social influence stress has a negative relationship with Job performance.

\subsection{Research Framework}

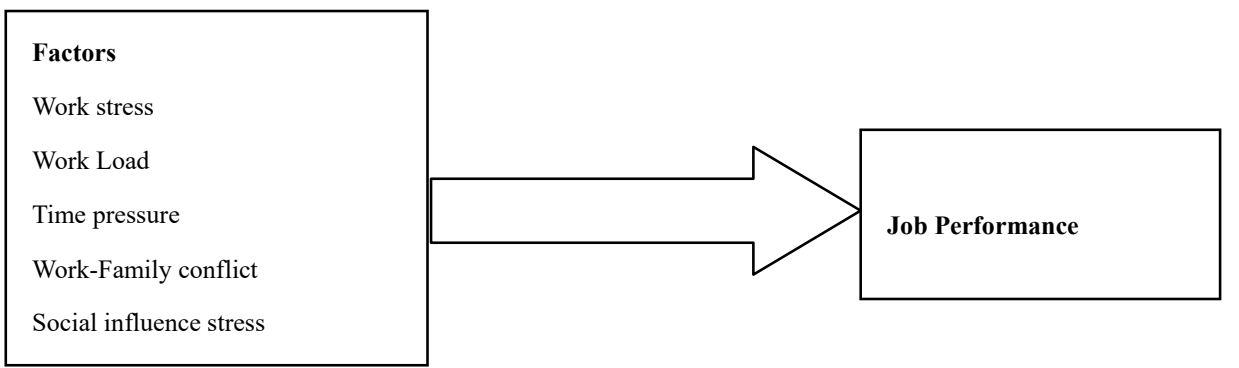

Source: Adapted from Viator (2001); Ahmad (2008); Mohd Nor(2011); Sulityawati, Janie, and Sulistyanti (2011) Suhayati (2012). 


\section{Sampling, Measurement, and Methods}

Hospital administrative staffs who currently attached to the Hospitals of the Selangor (Malaysia) State Government determined to be the target population of this study. There are eleven hospitals participating in this survey where the name of the hospitals cannot reveal. The targeted population is a set with specific elements related to (Zikmund, 2003) research project. Hospital administrative staffs have been selected as targets because they were involved as key personnel in the organization and administration of checking operation. Hospital administrative staff is an important focus for this study for several reasons. Hospital administration staff prone to the pressure of work. Therefore, the role of the administrative hospital staff will not only impact their capability of performing their job but also impacts the overall performance of the Hospitals. Addition to this, the hospital administrative staff were selected as the samples because there is no availability of previous studies regarding the administrative staff at the hospital and at the same time it gives a gap in this research.

The required 170 respondents were chosen to represent 300 administrative staff in the state of Selangor, Malaysia. 300 sets of questionnaires were distributed to total 185 and 15 questionnaires unable to process due to incomplete status. Hence, 170 questionnaires were successfully coerced and been analyzed. Self-administered questionnaires were used in this study. Questionnaires were distributed to the respondents by means of face-to-face. The main benefit of being able to be given a survey to collect data from a huge sample size. Meanwhile, a pilot test of 50 questionnaires that were conducted on a group of hospital administrative staff from different government hospitals in Peninsular Malaysia for the purpose of ensuring the questionnaire is to understand the target respondents. It is also to ensure that the research objective is related to the reliability and validity of the design of the questionnaire. In summary, among the 185 questionnaires, only 170 can be applied to the analysis after data screening and processing, missing values analysis, reverse coding, normality test, multicollinearity and "outliers' detection".

\section{Summary the Descriptive Analysis}

\subsection{Profile of Respondents}

Gender profile of the respondents, a total of 68 male respondents and 102 female respondents who contribute to 170. In percentage figures, there are $40 \%$ of male respondents and $60 \%$ of female respondents among 170 respondents in this gender classes. Most key respondents from this group are $48.8 \%$, consisting of 83 respondents aged from 31-40 years. The second largest is the respondents aged between $41-50$ years, who were 43 respondents representing $25.3 \%$ of the third group. Next is the respondents aged $21-30$ years consisting of 36 respondents who contributed $21.2 \%$. Finally, the smallest group is 51-60 years old, consisting of 8 respondents accounted for $4.7 \%$. When seeing on positions held by respondents in this sample, most of them are of an administrative assistant grade N17 which is $58.2 \%$, which consisted of 99 respondents. This was followed by the Assistant Administrative Officer N27 to contribute a percentage of $22.9 \%$, consisting of 39 respondents and categorized as the second highest. Position Customer Service Officer N 17 also represents 14.1\%, which comprises 24 general office assistant. Next N17 grade accounted for $4.7 \%$ of 8 people. Since most of them were people who hold administrative positions, the majority of respondents had at least STPM / Diploma which indicates $57.6 \%$ or 98 of the sample size. Next, it was followed by SPM / O levels contributed $32.4 \%$, consisting of 55 respondents. There are also respondents from category a bachelor's degree is $10 \%$, consisting of 17 respondents. However, other categories such as Masters and Ph.D. or professional responders are not included because the target is below the category title. Corner work experience most of them also have experience of working between 6-10 years accounted for $61.2 \%$, consisting of 104 respondents. The second highest number of respondents who contribute to the work of the service period of 10-15 years accounted for $16.5 \%$, consisting of 28 respondents. In addition, the service period for $1-5$ years showed 26 respondents, $15.3 \%$, and finally, there were 12 respondents who worked more than 16 years of $7.1 \%$. Finally, the revenue received is an important factor, the respondents in the sample of this size are of category RM1501-RM2500 monthly income that is 73 respondents, comprising $42.9 \%$ of the most supreme. Followed by the environment under RM2501-RM3500 monthly income comprised 61 respondents and contribute $35.9 \%$. Next, there were 24 respondents from between RM928-RM1500, which accounted for $14.1 \%$ and lastly, there were 12 respondents from RM3501-RM4500 category of $7.1 \%$. 


\subsection{Summary Inference Analysis}

\subsubsection{The Test Results Person Correlation}

\section{Correlations}

\begin{tabular}{|c|c|c|c|c|c|c|}
\hline & & $\begin{array}{l}\text { Work } \\
\text { stress }\end{array}$ & $\begin{array}{l}\text { Work } \\
\text { load }\end{array}$ & $\begin{array}{l}\text { Time } \\
\text { pressure }\end{array}$ & $\begin{array}{l}\text { Social } \\
\text { stress }\end{array}$ & $\begin{array}{l}\text { Work Life } \\
\text { conflict }\end{array}$ \\
\hline $\begin{array}{l}\text { Pearson } \\
\text { Correlation }\end{array}$ & 1.000 & $-.805^{* *}$ & $-.580^{* *}$ & $-.482^{* *}$ & $-.883^{* *}$ & $-.683^{* *}$ \\
\hline Sig. (2-tailed) & & .000 & .000 & .000 & .000 & .000 \\
\hline $\mathrm{N}$ & 170.000 & 170 & 170 & 170 & 170 & 170 \\
\hline
\end{tabular}

**. Correlation is significant at the 0.01 level (2-tailed).

Refer to the table on all the variables have a negative relationship where when each independent variable to be high, a decrease in the dependent variable according to the percentage of correlation.

\subsubsection{Results of Multiple Linear Regression (MLR)}

\section{Coefficients}

\begin{tabular}{|c|c|c|c|c|c|c|}
\hline \multirow[b]{2}{*}{ Model } & & \multicolumn{2}{|c|}{ Unstandardized Coefficients } & \multirow{2}{*}{$\begin{array}{l}\text { Standardized } \\
\text { Coefficients } \\
\text { Beta } \\
\end{array}$} & \multirow[b]{2}{*}{$\mathrm{t}$} & \multirow[b]{2}{*}{ Sig. } \\
\hline & & $\mathrm{B}$ & Std. Error & & & \\
\hline \multirow[t]{6}{*}{1} & (Constant) & 34.589 & 1.269 & & 27.259 & .000 \\
\hline & Work stress & -.769 & .141 & -.532 & -5.470 & .000 \\
\hline & Work load & .506 & .098 & .342 & 5.165 & .000 \\
\hline & Time pressure & -.220 & .055 & -.147 & -4.014 & .000 \\
\hline & Social influence Stress & -.625 & .095 & -.512 & -6.566 & .000 \\
\hline & Work life conflict & -.137 & .055 & -.113 & -2.503 & .013 \\
\hline a. Depe & ent Variable: Job perform & & & & & \\
\hline
\end{tabular}

From the table above, the variables of work stress have a significant relationship with the dependent variable. Therefore, the null hypothesis for all variables must be rejected additionally, $\beta$ or incline reflect that there exists a negative correlation between all IVs and job performance. This equation also describes that for every increase in the work stress, workload, and time pressure, work-life conflict and stress social influence, there is a decline in job performance by 0.769 (Role pressure) +0.506 (workload) +0.137 (Work-life conflict) +0.220 (time pressure) +0.625 (Influence of social pressure), respectively, provided that other variables remain unchanged.

\section{Discussion Main Findings}

Table 3. Summary of results hypothesis testing

\begin{tabular}{|c|c|c|c|c|}
\hline Bil & Hypothesis & Beta & P Value & Decision \\
\hline 1 & $\begin{array}{l}\text { H1: There is a negative relationship between work stress } \\
\text { and job performance of administrative staff. }\end{array}$ & -0.532 & 0.000 & Supported \\
\hline 2 & $\begin{array}{l}\mathrm{H} 2 \text { : There is a negative relationship between workload } \\
\text { and job Performance of administrative staff. }\end{array}$ & 0.342 & 0.000 & Supported \\
\hline 3 & $\begin{array}{l}\text { H3: There is a negative relationship between the time } \\
\text { pressure and job performance of administrative staff. }\end{array}$ & -0.147 & 0.000 & Supported \\
\hline 4 & $\begin{array}{l}\text { H4: There is a negative relationship between work-life } \\
\text { conflict and job performance of administrative staff. }\end{array}$ & -0.113 & 0.013 & Supported \\
\hline 5. & $\begin{array}{l}\text { H5: There is a negative relationship between social } \\
\text { influence stress and Job performance of administrative } \\
\text { staff. }\end{array}$ & -0.512 & 0.000 & Supported \\
\hline
\end{tabular}

Source: Developed for research.

The first discovery research, H1 is supported. It indicates that the negative work stress related to job performance. 
MLR results showed that $\mathrm{H} 1$ is supported whereby the p-value (0.000) is less than 0.05 with the beta of -0.532 which explains $53.2 \%$ of job performance is impaired due to work pressure. This statement is agreed by Mohd Nor (2011) where job performance has a negative relationship which will impact on the quality of an employee.

The second hypothesis shows that the workload has significantly related to job performance with $0.000 \mathrm{p}$-values. This result is consistent with the study conducted by Manzoor, Clouds, and Marian, (2012); Ladebo and Awotunde, (2007) who has established employee's performance is not significant to workload. Meanwhile, the $\mathrm{p}$-value of time pressure shows 0.000 which is lesser than 0.05 , and the beta is -0.147 . Thus, the hypothesis (H3) is supported. This result is consistent with the findings obtained by Wallace et al., (2009), which time pressure will affect the efficiency of an employee as may have one or errors in the statement of work may occur.

In addition, the $\mathrm{H} 4$ is also supported. It shows that work-life conflict has a significant relationship with job performance with 0.013 which is less than 0.05 . This statement explained that $11.3 \%$ of performance is deteriorated due to work-life conflict. This result is associated with significant life satisfaction and job performance (Gilboa et al. 2008; Bhuian, Menguc, and Borsboom,2003).

The last hypothesis, H5 is also supported. It shows that stress is a negative social impact related to the job performance of administrative staff. -0.512 is obtained from the study and it's supported by Clayton et al. (2010) in his research where the pressure of social influence has a negative relationship with the employee's job performance. It is because consideration and decisions will be affected by the pressure of social influences.

In conclusion, employee's performance influenced by all the variables, namely work stress, time pressure, the pressure of social influence, workload and work-life conflict. The variables show significant negative relationship on job performance among administrative staff $r$ square 0.830 while the adjusted $r$ square is 0.825 . Its mean that the model is good because as suggested by Cohen (1988) the $r$ square should be more than 0.26 . Its mean that $82.5 \%$ of the dependent variables can explain by all the independent variables in this study.

\section{Conclusion and Recommendations}

As a conclusion, the overall summaries, implications, limitations, and recommendation are discussed in this chapter. From this study, the role of stress has been found to be significantly correlated with the highest performance, which the management of Hospital should provide some related courses that guide the workers to deal with conflict resolutions. Employers also should be transparent of their organizations objective so that the employees are clear on the different tasks required by the management. The limitations were only hospitals in one state in Malaysia (Selangor) included in this study and 170 targeted respondents will not be sufficient to describe all hospital employees in Peninsula Malaysia. The result will be useful for upcoming researchers. As well as it will help the hospitals can be better organization in addressing the press work. This will be the recommendation for future research, which the upcoming research should include workers in East Malaysia as their target respondents. Along with the increase in the size of the samples,

It will increase the probability to represent the population. It is also recommended to use other methods of data collection such as interviews. As a conclusion, this research has resulted in how to enhance employee performance by understanding the behavior and attitudes of Hospital staff against work stress.

\section{References}

Ahmad, A. (2008). Job, Family and Individual Factors as Predictors of Work-Family Conflict. The Journal of Human Resource and Adult Learning, 4(1), 57-65.

Ahmad, Z., \& Taylor, D. (2009). Commitment to independence by internal auditors: the effects of role ambiguity and role conflict. Managerial Auditing Journal, 24(9), 899-925. https://doi.org/10.1108/02686900910994827

Ahson Umar, A. A. (2004). Dimensions of pressures faced by auditors and its impact on auditors' independence: A comparative study of the USA and Australia. Managerial Auditing Journal, 19(1), 99-116. https://doi.org/10.1108/02686900410509848

Al-Shami, S. A., Md Rawi, C. S., Ahmad, A. H., Abdul Hamid, S., \& Mohd Nor, S. A. (2011). Influence of agricultural, industrial, and anthropogenic stresses on the distribution and diversity of macroinvertebrates in Juru River Basin, Penang, Malaysia. Ecotoxicology and Environmental Safety, 74(5), 1195-1202. https://doi.org/10.1016/j.ecoenv.2011.02.022

Aranđelović, M., Ilić, I., \& Levi, L. (2006). Stress in workplace -possible prevention. Medicine and Biology, 13(3), 139-144.

Ashfaq, S., Mahmood, Z., \& Ahmad, M. (2013). Impact of Work-Life Conflict and Workover Load on Employee 
Performance in Banking Sector of Pakistan. Middle-East Journal of Scientific Research, 14(5), 688-695. https://doi.org/10.5829/idosi.mejsr.2013.14.5.1754

Bhuian, S. N., Menguc, B., \& Borsboom, R. (2005). Stressors and job outcomes in sales: A triphasic model versus a linear-quadratic-interactive model. Journal of Business Research, 58(2 SPEC.ISS.), 141-150. https://doi.org/10.1016/S0148-2963(03)00132-2

Braun, K., Lange, E., Metzger, M., \& Poeggel, G. (2000). Maternal separation followed by early social deprivation affects the development of monoaminergic fiber systems in the medial prefrontal cortex of Octodon degus. TL-95. Neuroscience, 95(1), 309-318. Retrieved from http://www.ncbi.nlm.nih.gov/pubmed/10619487

Bruggen, A. (2015). An empirical investigation of the relationship between workload and performance. Management Decision, 53(10), 2377-2389. https://doi.org/https://doi.org/10.1108/

Chong, V. K., \& Syarifuddin, I. (2010). The effect of obedience pressure and authoritarianism on managers' project evaluation decisions. Advances in Accounting, 26(2), 185-194. https://doi.org/10.1016/j.adiac.2010.04.004

Choudhary, N., Naqshbandi, M. M., Philip, P. J., \& Kumar, R. (2017). Employee job performance: The interplay of leaders' emotion management ability and employee perception of job characteristics. Journal of Management Development, 36(8), 1087-1098. https://doi.org/10.1108/JMD-10-2016-0195

Clayton, B. M., \& van Staden, C. J. (2015). The Impact of Social Influence Pressure on the Ethical Decision Making of Professional Accountants: Australian and New Zealand Evidence. Australian Accounting Review, 25(4), 372-388. https://doi.org/10.1111/auar.12077

Clayton, P. H., Bringle, R. G., \& Morrison, M. (2010). Differentiating and assessing relationships in service-learning and civic engagement: Exploitative, transactional, or transformational. Michigan Journal of Community Service Learning, Spring, 5-22.

Cohen, J. (1988). Statistical Power Analysis for the Behavioral Sciences. Mahwah, NJ: Lawrence Erlbaum

Cooper, C. L., Rout, U., \& Faragher, B. (1989). Mental health, job satisfaction, and job stress among general practitioners. BMJ (Clinical Research Ed.), 298(6670), 366-370. https://doi.org/10.1136/bmj.298.6670.366

Daugherty, B., Dickins, D., \& Higgs, J. (2009). Audit partner rotation: An analysis of benefits and costs. Retrieved from http://aaahq.org/meetings/AUD2010/AuditPartnerRotation.pdf

De Cremer, D., Van Dick, R., \& Murnighan, J. K. (2011). Social psychology and organizations. Social Psychology and Organizations. https://doi.org/10.4324/9780203846957

Fogarty, T. J., Singh, J., Rhoads, G. K., \& Moore, R. K. (2000). Antecedents and Consequences of Burnout in Accounting: Beyond the Role Stress Model. Behavioral Research in Accounting, 12, 31. https://doi.org/10.1108/EJM-12-2013-0739

Gilboa, S., Shirom, A., Fried, Y., \& Cooper, C. (2008). A meta-analysis of work demand stressors and job performance: Examining main and moderating effects. Personnel Psychology, 61(2), 227-271. https://doi.org/10.1111/j.1744-6570.2008.00113.x

Golden, T. D., \& Gajendran, R. S. (2018). Unpacking the Role of a Telecommuter's Job in Their Performance: Examining Job Complexity, Problem Solving, Interdependence, and Social Support. Journal of Business and Psychology, 1-15. https://doi.org/10.1007/s10869-018-9530-4

Golden, T. D., \& Veiga, J. F. (2016). Self-estrangement's toll on job performance: The pivotal role of social exchange relationships with coworkers. Journal of Management, Pre-Publis(X), 1-25. https://doi.org/10.1177/0149206315615400

Hsieh, H. L., Huang, L. C., \& Su, K. J. (2004). Work Stress and Job Performance in the Hi-Tech Industry: A Closer View for Vocational Education. World Transactions on Engineering and Technology Education, 3(1), $147-150$.

June, S., \& Rosli, M. (2011). The relationship between role ambiguity, competency and person-job fit with the job performance of employees in the service sector SMEs in Malaysia. Business Management Dynamics, 1(2), 79-98. https://doi.org/2047-7031

Kazmi, R., Amjad, S., \& Khan, D. (2008). Occupational Stress and Its Effect on Job Performance. A Case Studyof Medical House Officers of District Abbottabad. Journal of Ayub Medical College, Abbottabad: 
$J A M C, 20(3), 135-139$. Retrieved from http://www.ncbi.nlm.nih.gov/pubmed/19610539

Kelley, A. E., Baldo, B. A., Pratt, W. E., \& Will, M. J. (2005). Corticostriatal-hypothalamic circuitry and food motivation: Integration of energy, action, and reward. In Physiology and Behavior (Vol. 86, pp. 773-795). https://doi.org/10.1016/j.physbeh.2005.08.066

Khan, R. A., Khan, F. A., Khan, D. M., \& Shakeel, M. (2011). Impact of flexible scheduling on employee performance regarding stress and work-family conflict. Far East Journal of Psychology and Business, 4(3), $1-13$.

Ladebo, O. J., Awotunde, J. M., \& AbdulSalaam-Saghir, P. (2008). Coworkers' and supervisor interactionaljustice: Correlates of extension personnel's job satisfaction, distress, and aggressive behavior. Journal of Behavioral \& Applied Management, 9(2), 206-225.

López, D. M., \& Peters, G. F. (2012). The effect of workload compression on audit quality. Auditing, 31(4), 139-165. https://doi.org/10.2308/ajpt-10305

Lord, A. T., \& DeZoort, F. T. (2001). The impact of commitment and moral reasoning on auditors' responses to social influence pressure. Accounting, Organizations and Society, 26(3), 215-235. https://doi.org/10.1016/S0361-3682(00)00022-2

Mansoor, M., Fida, S., Nasir, S., \& Zubair, A. (2011). The Impact of Job Stress on Employee Job Satisfaction A Study on Telecommunication Sector of Pakistan. Journal of Business Studies Quarterly, 2(3), 50-56.

Mulki, J. P., Jaramillo, F., Goad, E. A., \& Pesquera, M. R. (2015). Regulation of emotions, interpersonal conflict, and job performance for salespeople. Journal of Business Research, 68(3), 623-630. https://doi.org/http://dx.doi.org/10.1016/j.jbusres.2014.08.009

Mulki, J. P., Jaramillo, F., Goad, E. A., \& Pesquera, M. R. (2015). Regulation of emotions, interpersonal conflict, and job performance for salespeople. Journal of Business Research, 68(3), 623-630. https://doi.org/http://dx.doi.org/10.1016/j.jbusres.2014.08.009

Naqshbandi, M. M., Garib Singh, S. K., \& Ma, P. (2016). The link between organisational citizenship behaviours and open innovation: A case of Malaysian high-tech sector. IIMB Management Review, 28(4), $200-211$. https://doi.org/10.1016/j.iimb.2016.08.008

Naqshbandi, M. M., Kaur, S., Sehgal, R., \& Subramaniam, I. D. (2015). Organizational culture profile of Malaysian high-tech industries. Asia-Pacific Journal of Business Administration, 7(1), 2-19. https://doi.org/10.1108/APJBA-08-2013-0088

Neuman, W. L. (2006). Social Research Methods. Sydney: Pearson Education.

Noor, N. M. (2003). Work- and family-related variables, work-family conflict, and women's well-being: Some observations. Community, Work, and Family, 6(3), 297-319. https://doi.org/10.1080/1366880032000143474

Oron-Gilad, T., Szalma, J. L., Stafford, S. C., \& Hancock, P. A. (2008). The workload and performance relationship in the real world: A study of police officers in a field shooting exercise. International Journal of Occupational Safety and Ergonomics, 14(2), 119-131. https://doi.org/10.1080/10803548.2008.11076757

Pasha, O., Poister, T. H., Wright, B. E., \& Thomas, J. C. (2017). Transformational Leadership and Mission Valence of Employees: The Varying Effects by Organizational Level. Public Performance and Management Review, 40(4), 722-740. https://doi.org/10.1080/15309576.2017.1335220

Wallace, J. C., Edwards, B. D., Arnold, T., Frazier, M. L., \& Finch, D. M. (2009). Work stressors, role-based performance, and the moderating influence of organizational support. The Journal of Applied Psychology, 94(1), 254-262. https://doi.org/10.1037/a0013090

Yahaya, A., Yahaya, N., Bon, A. T., Ismail, S., \& Ing, T. C. (2011). Stress level and its influencing factors amongemployees in a plastic manufacturing and the implication towards work performance. Elixir Online, 41, 5932-5941. https://doi.org/10.2224/sbp.2011.39.1.21

Zikmund, W. G., Carr, J. C., Griffi, M., \& Babin, B. J. (2013). Business Research Methods. South-Western, Cengage Learning (Vol. 8). https://doi.org/9781285401188 


\section{Copyrights}

Copyright for this article is retained by the author(s), with first publication rights granted to the journal.

This is an open-access article distributed under the terms and conditions of the Creative Commons Attribution license (http://creativecommons.org/licenses/by/4.0/). 